\title{
Poesía joven y fin del siglo XX: contrapuntos entre Perú y Chile a partir de Pista de baile de Martín Rodríguez-Gaona y La insidia del sol sobre las cosas de Germán Carrasco ${ }^{1}$
}

Young poetry and the end of the 20th century: counterpoint between Peru and Chile from Pista de baile by Martín Rodríguez-Gaona and La insidia del sol sobre las cosas by Germán Carrasco

Luis Fernando Chueca Universidad de Lima lvisfchueca@gmail.com

\section{Resumen}

El artículo revisa los poemarios Pista de baile del peruano Martín Rodríguez-Gaona y La insidia del sol sobre las cosas del chileno Germán Carrasco a fin de establecer un diálogo entre los rasgos de la poesía joven a fines del siglo XX, en ambos países, con los aspectos comunes de sus contextos de producción, a fin de indagar en cómo estos intervinieron en las subjetividades juveniles y cómo se expresaron desde la poesía.

Palabras clave: poesía peruana, poesía chilena, Martín Rodríguez-Gaona, Germán Carrasco.

\section{Abstract}

The article reviews the poetry books Pista de baile of the Peruvian Martín Rodríguez-Gaona and La insidia del sol sobre las cosas of the Chilean Germán Carrasco in order to establish a dialogue between the features of young poetry at the end of the 20th century, in both countries, with the common aspects of their production contexts, in order to investigate how they intervened in youth subjectivities and how they were expressed from poetry.

Keywords: Peruvian poetry, Chilean poetry, Martín Rodríguez-Gaona, Germán Carrasco.

Recibido: 28/03/2019

Aceptado: 15/11/2019

1 Este trabajo forma parte del Proyecto "Perú y Chile: escenarios convergentes en la poesía de la promoción de los noventa", que desarrollé como Investigador Responsable durante el año 2018 con el apoyo del Instituto de Investigación de la Universidad de Lima. 


\section{Introducción}

En el marco de las aproximaciones a la poesía joven latinoamericana de fines del siglo XX, resulta interesante indagar en las correspondencias entre los casos de Chile y Perú, pues, como se propone en este artículo, lo ocurrido en ambos países en los ámbitos sociopolítico, económico, ideológico y cultural, pese a las innegables diferencias, fue procesado de modos semejantes desde las subjetividades juveniles y específicamente desde la poesía de quienes comenzaron a publicar en dicho momento, los llamados "poetas de los 90". Aunque no existen trabajos comparativos previos al respecto, la bibliografía que ha abordado por separado cada uno de estos escenarios permite identificar algunas características comunes entre ambos. ${ }^{2}$ Entre estas destaca, en primer lugar, y de modo más notorio que en otras zonas del continente, la diversidad de registros poéticos, que contrasta con una definición clara de líneas hegemónicas en las promociones anteriores. ${ }^{3}$ Esta multiplicidad se afirmó a la par que el alejamiento de la experimentalidad, de las opciones vanguardistas, del espíritu gregario y la actitud parricida. Se disiparon también los entusiasmos sobre las posibilidades políticas de la poesía y, con ellos, las expectativas utópicas y el interés por las instancias colectivas. Todo esto redundó en una mayor atención a los espacios privados en desmedro de la mirada exteriorista y en cierta apuesta por el virtuosismo o la corrección formal del poema.

Varios de estos rasgos podrían extenderse al conjunto del continente, en donde en esos momentos se hacía patente lo que el crítico y poeta venezolano Gustavo Guerrero ha calificado como el "fin del sistema poético" (14), que implicó:

... un cuestionamiento de los modelos de escritura que dependían de él. . . [y] también de las maneras de leer, de apreciar y de evaluar; . . las perspectivas, los instrumentos y los valores con los cuales se construyó durante doscientos años un concepto del arte poética y de su campo de estudio (22). ${ }^{4}$

2 Tengo en cuenta para el caso chileno lo propuesto por Bello, Morales, Véjar, Lange, Sepúlveda, Mansilla y Eguiluz, y para el peruano por Chueca, Mazzotti, Bernales y Villacorta, Ildefonso y Guillén, además de lo comentado por los propios poetas en diversas entrevistas.

3 Lo conversacional, en sus diversas posibilidades, en el caso peruano (ver Chueca, "Consagración..." y “¿La hegemonía...?”) y la experimentalidad neovanguardista en Chile (ver Brito, Rioseco, Lange).

4 Sintetizando algunas ideas de Cárcamo-Huechante y Mazzotti, Ortega, Cerón et al., Milán y Dobry, se pueden apuntar algunos otros aspectos claves en ese contexto: la atomización del concepto de poesía, por lo general concebida como acto casi cerrado en sí mismo, sin mayores implicancias que excedan al texto, la diversificación de bibliotecas e hibridación de los textos, el triunfo del individualismo, el rechazo de la posibilidad de una estética dominante o de opciones monológicas excluyentes y la fractura de los circuitos de comunicación poética (frente al predominio del mercado literario más superficial) que 
No obstante, la mayor incidencia de las primeras características mencionadas en estos dos países, posibles de vincular con contextos de violencia o posviolencia en que se consolidaban los sentidos comunes de la posmodernidad neoliberal, justifican y hacen interesante la revisión comparativa entre estos dos escenarios.

No es posible emprender aquí un análisis en detalle de lo apuntado en relación con los distintos poetas de uno y otro país. Por ello, este trabajo propone, luego de un marco general, indagar — a modo de muestra y adelanto de una tarea mayor ${ }^{5}$ cómo se procesaron algunos de los cambios en las mentalidades y subjetividades de su tiempo en dos poemarios representativos de este momento de tránsito, uno de cada país: Pista de baile (1997) de Martín-Rodríguez-Gaona (Lima, 1969) y La insidia del sol sobre las cosas (1998) de Germán Carrasco (Santiago, 1971). Ambos poemarios están entre los más interesantes entre los publicados por poetas jóvenes en la década de los noventa. Además, comparten la atención prioritaria al espacio urbano y ofrecen, a partir de hablantes configurados como poetas-paseantes ( $f \hat{a}$ neurs), potentes imágenes de la ciudad, aspectos que constituyen una línea central en esta revisión.

\section{Perú y Chile: contextos y nuevas coordenadas en la poesía joven en los 90}

Resulta necesario preguntarse, en primer lugar, qué representa en los contextos peruano y chileno la coexistencia sin reparos ni mala conciencia entre poetas conversacionales (culturalistas o coloquiales), líricos e intimistas, entre herederos de las tradiciones indígenas y clasicistas, o entre neobarrocos, minimalistas, objetivistas, surrealizantes y desrealizadores. Se puede considerar, al respecto, la necesidad de diferenciación como estrategia de incorporación de en el campo literario o frente a la percepción de agotamiento de algunas posibilidades estéticas. No obstante, la diversidad, así como los otros rasgos señalados, difícilmente se pueden comprender a cabalidad sin atender a los procesos y circunstancias, locales y globales, que provocaron un clima de desconcierto, desencanto e incertidumbre en los jóvenes de ambos países, quizá de modo más intenso que en otros.

provocó la reducción del número de lectores de poesía (a pesar de las posibilidades tecnológicas de la globalización).

5 En general, son todavía pocas las revisiones de conjunto sobre esta promoción en cada uno de estos países. En el proyecto en el que este artículo se inscribe, he contemplado también textos de la peruana Montserrat Álvarez y la chilena Verónica Jiménez, y la posibilidad de trazar diálogos diversos entre los libros iniciales de estos cuatro poetas en relación con sus contextos de producción. Una línea complementaria a este proyecto es la indagación sobre los cambios que se producen en sus obras - y en general en el conjunto de los "poetas de los noventa"- luego de sus primeras entregas. 
Entre los eventos globales del fin del siglo, ${ }^{6}$ destacan la caída del muro de Berlín (1989) y de la Unión Soviética (1991). Ambos hechos, celebrados como los inicios de una fiesta democrática, contribuyeron a diluir, entre la entusiasta difusión del paradigma posmoderno de la "descomposición de los grandes Relatos" (Lyotard 36), los restos de las utopías de las generaciones anteriores. Se consolidó así la lógica del mundo globalizado y unipolar del capitalismo tardío, el neoliberalismo y el "fin de la historia" a partir de la supuesta conducción de "la mayor parte de la humanidad hacia la democracia liberal” (Fukuyama 13) y su complemento, la economía liberal.

Desechada casi toda pretensión de transformación radical de las estructuras sociales, se prefería, cínicamente, disfrutar de los espejismos del mercado y el consumo, de la plena disponibilidad de lo deseado y de la velocidad que acortaba distancias y eliminaba fronteras, antes que atender a las contrapartes de ese mismo proceso: la pérdida de un lugar propio y del sentido de pertenencia, así como las evidencias de las "vidas desperdiciadas" y "los residuos del progreso económico" (Bauman 51) y la globalización, la distancia entre centros y periferias o la reactivación de la xenofobia (Grüner 12-23). En ese marco, la desmotivación política generada por el colapso de los proyectos socialistas produjo, sobre todo en los más jóvenes, una gran "orfandad existencial" (Hopenhayn 29), toda vez que la modernización-en-globalización tiende a la "des-identidad, a la des-habitación, a des-singularizar a sus habitantes" (27).

Esto alcanzó también a América Latina, en donde si bien no se podía hablar de plena modernidad, la posmodernidad se fue implantando como ideología y dominante cultural, asociada, según apunta teórico norteamericano Fredric Jameson (1995), a la lógica del consumo y a la transformación de casi todo en mercancía, a la crisis de la historicidad en favor del historicismo y a la pérdida de los afectos, de la distancia crítica y de las utopías del modernismo, en un contexto que promovía el mercado y la globalización como horizontes fundamentales. En el campo de las artes estos procesos implicaron la exploración intensa de posibilidades estéticas a partir de la confluencia de diversos estilos y registros, del reciclaje y el pastiche, y de la apelación al kitsch y la cultura de masas, en consonancia con la desconfianza respecto de la idea de la originalidad creativa y del autor.

En el Perú, el impacto del mundo post muro de Berlín se conjugó, en el cambio de década, con las consecuencias de la violencia política creciente en las

6 Hobsbawn señala que "es indudable que en los años finales de la década de 1980 y en los primeros de la de 1990 terminó una época de la historia del mundo para comenzar otra nueva” (15). 
ciudades, ${ }^{7}$ la corrupción, el caos y el colapso del Estado, que provocaron el quiebre del sistema partidario, el surgimiento de los políticos "independientes", una mayor desinstitucionalización y el "ascenso de la antipolítica" (Degregori 27-44). En este contexto, Alberto Fujimori fue elegido presidente en 1990 y, no obstante su discurso populista y su crítica a la política del shock como correctivo frente a la hiperinflación que afectaba al país — preconizada por Mario Vargas Llosa, su contendor-, la aplicó e impulsó una versión peruana del neoliberalismo, consolidada luego del "autogolpe" de 1992.

Con el control de los poderes del Estado desde el gobierno y con una represión focalizada que provocó la desmovilización de organizaciones sindicales, sociales y del pensamiento crítico, se afirmó la impresión de un mayor orden social, sobre todo después de la captura de Abimael Guzmán y de la cúpula de Sendero Luminoso. Pero la "pacificación" y la "reconstrucción nacional", celebradas por muchos con optimismo por el horizonte de tranquilidad que aparentemente propiciaban, involucraron, además de una marcada sensación de vigilancia ${ }^{9}$ y de urgencias de supervivencia económica, una corrupción institucionalizada a gran escala y la explotación extrema de las posibilidades de la manipulación mediática.

En paralelo, el campo literario resiente la retracción en la atención hacia la poesía y, en general, hacia la literatura ajena a las dinámicas del mercado, por parte de la prensa cultural, cuyos espacios también se vieron disminuidos. Esto, sumado al mínimo interés de la crítica académica por la producción reciente, provocó que los poetas jóvenes recibieran muy poca retroalimentación, más allá de la brindada por sus pares generacionales.

7 A partir del inicio, en 1986, del llamado período de "despliegue nacional" de la violencia (CVR 69-71), se incrementan notablemente las acciones armadas en los escenarios urbanos, en general, y en Lima, en particular. Esto se agrava hacia 1989 con el llamado período de "crisis extrema" (71-74) iniciado a partir de la decisión de Sendero Luminoso de impulsar el "equilibrio estratégico" en la perspectiva de la toma del poder y de la nueva estrategia de respuesta del estado, que contemplaba "violaciones de los derechos humanos menos numerosas pero más premeditadas" (72). Se intensifican en estos años en Lima declaratorias de toques de queda, estallidos de coches-bomba, acciones de comandos de aniquilamiento, incursiones policiales en barrios periféricos, etc.

8 Degregori toma el término de un trabajo de Nicolás Lynch: "Lynch define la antipolítica como un conjunto de discursos y prácticas que satanizan la política como actividad pública e institucionalizada y pretenden su reemplazo por mecanismos 'naturales' como el mercado, cuya vigilancia está a cargo de técnicos que brindan soluciones prácticas a problemas específicos" (20).

9 Vinculada con la represión focalizada que apuntaba a la desarticulación y desmovilización de los sectores más críticos de las políticas del gobierno. 
En Chile, en 1990, se retornó a la democracia luego de diecisiete años de dictadura. Pero, paradójicamente, en lugar de recuperar las expectativas de una sociedad de justicia plena e igualdad, la Transición significó la aceptación institucional de que había que recortar los horizontes de la utopía, "ajustarse a lo posible", sobre todo ante el miedo frente a un posible retorno del autoritarismo militar. Una "democracia limitada" (Ruiz 15) o "protegida" (Moulian 53) con decisivas continuidades respecto de los modelos de funcionamiento social y económico implantados por la dictadura. Se favoreció así la consolidación, legitimada ahora por la democracia, de un modelo de economía de mercado y de consumo en la órbita neoliberal, junto al ideario del "blanqueo", el consenso y el "bloqueo de la memoria" (Moulian $37-$ 50), que no pudieron ocultar las tensiones entre "dejar atrás, olvidar, derrumbar, reprimir, y traer hacia delante, recordar, construir y exhibir” (Sepúlveda 155). El retorno a la democracia significó también para muchos jóvenes el reingreso a un espacio social conflictivo respecto de la posibilidad de encontrar un lugar propio, lo mismo que la percepción de un clima de vigilancia asociado a los discursos sobre la necesidad de seguridad.

De las síntesis anteriores se desprende que en ambos países se consolidó el paradigma ideológico-cultural neoliberal ${ }^{10}$ expresado en la retracción o pérdida del interés por lo colectivo en beneficio de lo privado y el individualismo, la cultura del éxito - más fuerte en el campo literario desde la instalación de las editoriales transnacionales - y el crédito, la sensación de vigilancia y las restricciones al ejercicio de la memoria. También en el aumento de la velocidad comunicacional y de las prácticas cotidianas, y en la mayor intensidad de los intercambios e hibridaciones culturales.

Es reconocible, asimismo, en ambos países, un "vaciamiento simbólico" (Rowe): un violento ataque ${ }^{11}$ contra identidades no funcionales a los nuevos modelos de desarrollo, que declara inviables las ideologías izquierdistas creando "un vacío ético y político sólo capaz de llenarse por la modernización neoliberal” (Rowe 74). Esto, mencionado para casos como el peruano, coincide con lo que sociólogo Tomás Moulian apunta sobre Chile: "el debilitamiento de los sistemas discursivos alternativos al neoliberalismo y la capacidad manifestada por este para seducir y

10 Se puede hablar de consolidación en el caso de Chile, en que el neoliberalismo comienza pocos años después de iniciada la dictadura, en tanto se legitima con la democracia, al margen de la intensidad represiva que había hecho posible su implementación. Esto significó un choque sobre todo para muchos jóvenes que esperaban que el retorno a la democracia supusiera tajantes modificaciones respecto del modelo impuesto.

11 Sumado, más claramente en el Perú, al agravamiento de las condiciones económicas y la precariedad laboral. 
atraer o, de un modo más pasivo, para presentarse como el único horizonte posible de quienes antes tenían otras perspectivas ideológicas" (58).

Si previamente al "vaciamiento simbólico" hubo, a pesar de la violencia, la represión o el miedo, una intensa actividad de resistencia directa y simbólica, y se desarrolló un potente pensamiento crítico, los años noventa representan un momento de desmovilización en el que, sin embargo, diversas prácticas - entre ellas las poéticas, aunque en menor magnitud que antes - buscaron seguir ejerciendo miradas críticas frente al entorno. Esto entre los desconciertos y desencantos que envolvían, en general, la subjetividad de los jóvenes poetas.

Roger Santiváñez, poeta peruano de la promoción anterior, con ocasión de las violentas muertes en 1994 y 1996, respectivamente, de Carlos Oliva y Juan Vega, dos poetas de los noventa, se refirió a “[e]sa desolación, esa desesperanza, esa nada que nos parece englobar, [y que] ... nos reúne finalizando el siglo y el milenio, cuando ya nadie cree en nadie" (s/p). Más adelante, Victoria Guerrero, también peruana y poeta de los noventa, calificó a la suya como "una generación malograda ... por la represión, por el miedo, por la violencia” (párr. 6). Por su parte, Javier Bello, poeta chileno de la década de los noventa, bautizó a sus contemporáneos como “náufragos”. Ese término “metaforiza ese 'espacio del desconcierto' del que se habla en la imagen principal que recorre toda esta temprana producción y que pone de relieve la aventura vital que en estos tiempos protagonizan los jóvenes: el contemplarse "perdidos"” (parte II, párr. 6).

A pesar de las diferencias entre ambos países, ${ }^{12}$ existen, como se observa, importantes puntos de contacto. Estos justifican la mirada en común y refuerzan el planteamiento de que los rasgos apuntados en las escenas poéticas no pueden verse sólo como resultado de preferencias estéticas particulares, como simple consecuencia de un deseo de diferenciación o como el eco inocente y optimista del momento posmoderno. Deben considerarse como expresiones en el campo poético de los procesos políticos y socioculturales en curso en ambas sociedades, que revelan, en gran medida, los modos en que los poetas los fueron afrontando.

Sin claridad respecto de lo que estos procesos significaban o hacia dónde conducían, es comprensible, trazadas las coordenadas del momento, que hubiera múltiples indagaciones inciertas que abandonaran la lógica de la confrontación como dispositivo predominante en la renovación poética. La desconfianza frente a las verdades totalizantes también se relaciona con la diversidad y la pérdida de con-

12 La más notoria es la del régimen político: la democracia reciente en Chile y la dictadura desde 1992 en Perú. 
vicciones vanguardistas, lo que refuerza, a su vez, en tiempos de retracción de lo colectivo: el abandono de la organización grupal alrededor de principios estéticos o políticos. ${ }^{13}$ Así, en momentos en que los poetas "perciben una amenaza constante que los lleva a crear bellos sustitutos" (Sepúlveda 160) y se vive cierta sensación de "sálvese quien pueda" poético "que desembocó en la construcción tímida de diversidad de casilleros, todos igualmente protegidos o desprotegidos" (Chueca, "¿La hegemonía...?” 140), resulta simplificador pensar que la poesía de la década de los noventa fue llanamente despolitizada o formalista o, peor, pobre o inocua, como varias veces se ha comentado. ${ }^{14}$

Es cierto que se puede observar, en general, un alejamiento del horizonte de politización explícita o al menos claramente reconocible, como el vivido hasta la década de los ochenta, lo mismo que una preocupación por el cuidado formal, que evita el experimentalismo o el vitalismo exacerbado. Pero ambos aspectos, como también los demás rasgos mencionados, deben revisarse a fin de evaluar cómo se presentan en los textos y qué implican. Es decir, de qué modo esta poesía, desde sus lenguajes, voces, tonos, estructuras, símbolos y referencias, expresa su mundaneidad: sus "modos de existencia .. . que están siempre enredados con la circunstancia, el tiempo, el lugar y la sociedad” (Said 54). A eso se dirige el siguiente acápite, en que revisaré los poemarios Pista de baile de Martín Rodríguez-Gaona

13 Los rasgos mencionados no aparecen de un día a otro o de un año a otro, sino a través de procesos de tránsito. Entre estos, el caso de la poeta de los años noventa Montserrat Álvarez en el Perú es emblemático, pues su Zona dark (1991) todavía tematiza la utopía (que aparece, aunque en crisis, en los poetas de la promoción anterior desde mediados de los 80), pero para negarla. En Chile, el tránsito podría estar representado por los poetas post 87 (cf. Gutiérrez), que todavía conservan algunos rasgos de experimentalismo vanguardista cercanos a los de la Escena de Avanzada, pero impregnados por una todavía mayor desconfianza o desinterés frente a lo utópico, de lo que se ven cada vez más distantes. Esto de la mano de una exploración de la marginalidad urbana.

14 Sobre todo entre los poetas más jóvenes. En Chile, Héctor Hernández Montecinos, poeta de la llamada "Novísima" de la década del 2000, ha criticado la poesía de la promoción anterior señalando que "significó un retorno al yo lírico" (126) por parte de quienes creen "en el poema y en la palabra, en su unidad como sistema cerrado" (128), lejos de "cualquier cosa que exceda al poema" (128), y que "si hiciera una antología de poesía política ninguno de los poetas de los noventa aparecería" (127). Pero a la vez, ha apuntado que "[e]l intimismo, el desmedro del nosotros con respecto a un yo situado y la literatura como materia prima de su propia literatura [de los poetas de los noventa] son temas que habría que leer desde una mirada que no soslaye su relación directa con la posdictadura, pero que tampoco la enjuicie moralmente” (125). En el Perú, José Carlos Yrigoyen, uno de los más jóvenes poetas de los noventa, ha insistido en diagnosticar una crisis en la poesía peruana desde mediados de los años ochenta que se agrava, a su juicio, con la promoción de los noventa (2008). Añade que los poetas de los noventa, salvo algunas excepciones, no dieron una obra de calidad, no fueron capaces de renovar el lenguaje y expresaron un gran conservadurismo frente a las posibilidades experimentales. 
y La insidia del sol sobre las cosas de Germán Carrasco atendiendo sobre todo a los poemas que inciden en una de las preocupaciones centrales en ambas tradiciones en la segunda mitad del siglo XX: la configuración del espacio urbano.

\section{Poesía y tránsitos urbanos hacia el fin de siglo XX en Lima y Santiago}

\section{Una Pista de baile entre el consumo y el amor hogareño}

Martín Rodríguez-Gaona profundizó, con Pista de baile (1997), su segundo poemario, lo ofrecido en Efectos personales, aparecido en 1993 (cf. Chueca, "He amado...", Salazar). Pero a la vez, como él mismo ha comentado, pasados los años más duros de la violencia en el Perú, se sintió más libre para abordar, ya no "de manera supuestamente objetiva ... otras problemáticas, sueños y deseos más personales, más egoístas incluso, pero que me tocaban con más intensidad” (de Lima). Así, con un lenguaje hipercoloquial que extrema el conversacionalismo hasta poner en cuestión la "condición poética" de algunos de sus versos, el poemario explora en una de sus líneas centrales el espacio urbano, configurando, a diferencia de la mayor parte sus contemporáneos también preocupados por las representaciones de la ciudad en la poesía, ${ }^{15}$ un universo cultural-juvenil vinculado con los sectores medios limeños de los años noventa.

Un poema fundamental para comprender cómo Pista de baile aborda las tensiones de las subjetividades juveniles en las coordenadas temporales anotadas es el extenso "Nada es nada en un lugar en que está a punto de suceder todo", del que cito unos fragmentos:

Los postes sonríen en las noches de verano bendiciendo todo lo que observan, dejando un espacio oscuro invisible para lo que está más allá de sus fuerzas.

$$
\begin{gathered}
\text { En Barranco, } \\
\text { barrio de luces para una generación, } \\
\text { siempre la misma gente, los que van para ver } \\
\text { y los que van para dejarse ver, } \\
\text { jóvenes } \\
\text { en su mayoría, bellos en su mayoría, ajenos } \\
\text { en su totalidad. }
\end{gathered}
$$

15 Como Montserrat Álvarez, Miguel Ildefonso, Carlos Oliva o Roxana Crisólogo, más atentos a la marginalidad urbana o los espacios suburbanos. 
Griteríos y una nueva

canción alternativa:

No,

nunca serán ajenos a ellos mismos.

Son ajenos al mundo, es decir,

a este servidor.

. .

¿Cuántas instituciones lanzan a sus críos

a la programática diversión de un fin de semana?

"Un viejo sifilítico con súbitos ímpetus lésbicos"

No lo sé, Papito, cuenta todos esos autos

y los colectivos,

tendrás un motivo para no ir a casa.

. .

Puedes pasear, emborracharte y vomitar mas a $9,000 \mathrm{Km}$

tu abuelo morirá sin haber visto

el rostro con el que despertarás mañana.

Eso y no otra cosa

es lo que las Dalinas llaman

“LA ALEGRÍA DE VIVIR". Los olvidos

nunca son gratuitos. En este mismo parque

unos cuantos ancianos te hacen recordar

las monedas que te sobran

para ser feliz.

Y todo simplemente por cuidarte

el carro-

"Ya, no grites que nos lleva el Serenazgo".

Lo único que queda ahora

es perseguir la emoción

y dibujar

luces, sonidos y olores

que hagan creer que esta noche

valdrá la pena (15-16; mayúsculas originales). 
Tal como ocurre en estos versos, todo el poema, de nueve páginas, se organiza a partir de la voz-escritura enunciada en presente por un sujeto-poeta ("Yo, por ejemplo, vine/ para escribir un poema" (20), el resaltado es mío) que recorre las calles nocturnas en un fin de semana del distrito de Barranco, asociado a la bohemia artística limeña y a la diversión juvenil. Como se observa, este paseante o flâneur contemporáneo intercala en su discurso imágenes captadas del entorno, impresiones sobre estas y el registro directo de voces de algunos de los personajes que pueblan este escenario. El resultado es un magma de palabras y frases muy oralizadas, pero también una materialidad visual dispuesta alternadamente hacia la izquierda, la derecha y el centro de la página. Las estrofas constituyen, así, estímulos como los que se van encontrando al caminar por estas calles bullentes de movimiento: retazos de experiencias múltiples, fugaces y en general superficiales propias de la cotidianeidad de las clases medias y acomodadas juveniles en sus aventuras callejeras de diversión. Entre estos hay imágenes de chicos y chicas que llegan a divertirse, referencias musicales, cantinas y restaurantes, olores y sabores, eslóganes televisivos, mendigos, vendedores ambulantes y cuidadores de automóviles, inscripciones amorosas en árboles, escenas de seducción, desagradables encuentros fortuitos, roedores en los jardines, luces deslumbrantes y zonas de oscuridad. Todo ello va configurando un imaginario cultural y simbólico intenso y fragmentario a través de un trabajo de montaje que "hace surgir y adjunta esas formas heterogéneas ignorando todo orden de grandeza, toda jerarquía” (Didi Huberman 99).

De este modo, el flâneur-poeta busca expresar el ritmo y el pulso de su vertiginoso recorrido, y apuesta a provocar en el lector la impresión de compartir con él, en simultáneo, esa experiencia, dirigiendo fugazmente la atención hacia cada nuevo estímulo/estrofa a través de las nueve páginas del poema. Esta dinámica, junto con unos versos que al inicio presentan a la mayoría de los transeúntes como "[i]óvenes/ en su mayoría, bellos en su mayoría, ajenos/ en su totalidad” (14) que son "siempre la misma gente, los que van para ver/ y los que van para dejarse ver" (14), provoca la impresión de estar ante un mercado de imágenes en donde el primer producto son los cuerpos que, como señala el filósofo coreano Byung-Chul Han, "con su valor de exposición equivale[n] a una mercancía” (23).

Desde esta pista, es posible asociar la lógica compositiva del poema con las operaciones de oferta y demanda de la posmodernidad neoliberal que iban asentándose en los momentos de escritura del poema, posiblemente hacia 1993 o 1994, según algunas referencias ofrecidas por el texto. ${ }^{16}$ Para esos años en que la intensidad de

16 En tanto se menciona al actor Julián Legaspi y la serie televisiva Calígula, transmitida en 1993, o las "Dalinas", conductoras del programa infantil Nubeluz, que comenzó a emitirse en 1990. 
la violencia armada había disminuido notoriamente ${ }^{17}$ y la hiperinflación se había detenido, muchos aceptaban entusiastas, en el contexto de la dictadura fujimorista, las múltiples "promesas" del modelo económico. Entre ellos los jóvenes, sobre todo de las clases medias y altas urbanas como los que retrata el poema, disfrutaban de las nuevas posibilidades del libre acceso a aquello (espacios, productos, experiencias) que pudieran comprar y que se había visto restringido por los peligros, el miedo y la crisis generalizada de los años anteriores.

Las eufóricas vivencias en ese mercado de sensaciones y emociones parecen protegerlos además de un verdadero contacto con la realidad. Por eso el poema los representa como "ajenos/ en su totalidad" (14): indiferentes a los cuestionamientos generados por las diferencias sociales ${ }^{18} \mathrm{y}$, sobre todo, a la ausencia de sentidos y la "orfandad existencial" (Hopenhayn 29) consecuencias del derrumbe de las utopías y el horizonte colectivo. Por ello también buscan, en las noches barranquinas, "LA ALEGRÍA DE VIVIR"19 o persiguen "la emoción", expresadas en la variedad, la velocidad, la disponibilidad y la "primacía del aquí y el ahora" (Lipovetsky 53) en las que se sumergen en sus paseos de fin de semana.

Por su parte, el flâneur-poeta, envuelto en ese mundo de imágenes, pretende, al modo del paseante benjamineano, capturarlas para hacerlas circular en el mercado (literario), ${ }^{20}$ a la vez que para convertirlas en imágenes dialécticas con las que procura "dissolver a 'mitologia' no espaço da história" (Bolle 61). Oscila de ese modo entre el deslumbramiento por lo que observa, perceptible en su animada participación en el recorrido callejero, y la sospecha o convicción de estar ante un escenario de simulacros en donde las cosas no responden al azar, sino a la voluntad de "instituciones" que "lanzan a sus críos / a la programática diversión de un fin de

17 A partir de la captura de Abimael Guzmán y la cúpula senderista, en 1992. La CVR califica a este período, que llega hasta noviembre de 2000, como "Declive de la acción subversiva, autoritarismo y corrupción" (74).

18 Que se solucionan, por ejemplo, con tranquilizadoras limosnas: "En este mismo parque/ unos cuantos ancianos te hacen recordar/ las monedas que te sobran/ para ser feliz" (16), o se muestran naturalizadas para los jóvenes transeúntes: "Señor, ¿por qué no pasea a su perro/ por su vereda?" (19; cursivas originales).

19 El verso, en reveladoras mayúsculas, remite a un lema cantado en el popular programa infantil Nubeluz, que comenzó a transmitirse en 1990 y que diseñó un mundo maravilloso de disfrute y plenitud. Esto ocurría, paradójicamente en una Lima de permanentes estallidos de coches-bomba. Paradójicamente también (aunque esto posiblemente corresponda a un momento posterior a la escritura del poema, pero anterior a su publicación) una de las dalinas, las conductoras del programa, se suicidó en 1994.

20 Es central, al respecto, la conciencia metapoética que anuncia la razón de su presencia allí: escribir un poema. 
semana" (15), algo requerido para el funcionamiento social. ${ }^{21}$ Así, bajo la radiante superficie de emociones al alcance, reconoce el vacío que genera una necesidad de "gratificación instantánea y . . . búsqueda del placer", funcional al sistema neoliberal, que el filósofo esloveno Slavoj Žižek menciona como tendencia central en la sociedad posmoderna (393). Esto se sintetiza, llevado al extremo, en la imagen de mayor crudeza del poema:

\section{Porque Barranco tiene su encanto:}

Podrías levantarte a una ruca y arrinconarla detrás de los jardines, pegarle, penetrarla, eyacular deliberadamente dentro para ser por una sola vez inmortal $(16)^{22}$

Con esta estrofa se refuerza la impresión de que la dinámica del consumo sugerida por el libre acceso a los estímulos no sólo funciona como dispositivo de reconocimiento y de prestigio, sino también como práctica productora de sentidos vitales en esta "era del vacío" (Lipovetsky). Con la crisis de las utopías y las identidades colectivas, y con la globalización como espejismo, pareciera que una de las pocas posibilidades para ello es la sensación de inmortalidad, incluso se pretenda a través a través de un disfrute sin ninguna consideración por nada más allá del propio deseo o necesidad. ${ }^{23}$ Superficialidad, ocaso de los afectos, debilitamiento de la historicidad, simultaneidad del presente — diría Jameson- que el poeta-flâneur hábilmente pone en la escena de un recorrido que a primera vista

$21 \mathrm{Al}$ respecto Lipovetsky apunta: "[l]a fuerza de los dispositivos subpolíticos del consumismo y la moda generalizada es lo que ha causado la derrota del heroísmo ideológico-político de la modernidad” (64).

22 "Ruca" en el sociolecto peruano juvenil remite, desde la perspectiva de una moral conservadora y machista, a una mujer que no ofrece mayores reparos frente a las posibilidades de disfrute erótico y sexual eventual. La estrofa es, a la vez, una buena muestra de la hipercoloquialidad que pone en cuestión el estatuto habitual de lo poético.

23 O, en otros ámbitos no abordados en Pista de baile, en el ejercicio de la violencia gregaria de las barras y pandillas que entonces proliferaban. Juan Carlos Ubilluz, desde el psicoanálisis lacaniano, señala que con la caída del horizonte utópico, “¿dónde encuentra el sujeto el sentido de su existencia en la realidad planetaria de la posmodernidad ... [S]i el Otro no existe, yo existo en un sistema -el capitalismo tardíoque me libera del compromiso social y legitima mi creencia narcisista en que yo soy el centro del mundo" $(21-22)$. 
parecía figurarse como la inocua y alegre observación de las posibilidades de diversión en los nuevos tiempos.

En el poema "Esperando en todos los umbrales", el hablante, que podemos identificar con el poeta-flâneur de "Nada es nada..." y de todo Pista de Baile, se sitúa de modo más explícito ante un mercado de ilusiones, aunque sin el grado de violencia de la cita anterior: "cuando salgo de mi casa/ . . paso todo el tiempo/ mirando mujeres. El sol de la ciudad/ nos brinda los regalos más inesperados-/ chicas en falda, blusas abiertas/ amarillos chocantes en piernas de arena/ C H O L A S/ ojos marrones, cabellos pintados brillando sobre la luz, / . . / ¡Mujeres cuyos cuerpos poseo en un segundo para la eternidad!/ . . / Nunca me han visto y siempre las acompaño/ en las esquinas, en los paraderos, cuando hacen/ filas para comprar mentiras" (48).

El instante aludido en "para ser por una sola vez/ inmortal" de "Nada es nada..." es análogo al "segundo para la eternidad" de este poema. Pero acá la necesidad compensatoria, focalizada en el propio flaneur, se enlaza a cierta incapacidad suya para erigirse en mercancía apetecible. Esto se observa en tanto las "[m] ujeres cuyos cuerpos poseo" (imaginariamente) "nunca me han visto". Vuelve a dejar constancia, así, de su complejidad como personaje, ${ }^{24}$ pues si bien responde, hasta cierto punto, a la búsqueda de placer exigida por la sociedad signada por el consumo neoliberal, y participa de prejuicios sociales, como el estereotipo sobre los "cabellos pintados" de las "CHOLAS/ de ojos marrones", a la vez percibe la dimensión de simulacro de este mercado donde se "hacen/ filas para comprar mentiras".

También son interesantes los versos “¿por qué si uno puede ver tres películas/ al mismo tiempo (con control remoto)/ uno no puede tener tres mujeres/ bajo un mismo techo (con remoto control)?" (25) del poema "Lo que producen las películas francesas (Homenaje a Noches de Luna Llena)". Por un lado, porque refuerzan la percepción de la tendencia de los jóvenes representados en los poemas, incluido el hablante-poeta, de diseñar un "mundo [que] se le[s] presenta sólo como proyecciones de sí mismo[s]" (Han 11), organizado en función casi exclusiva de sus propias imágenes y necesidades. Por otro, por la mención del control remoto, que permite asociar este dispositivo emblemático de la cultura posmoderna (Sarlo, Escenas 55-71) con el modo de operar del flâneur-poeta en "Nada es nada...". Desde esta perspectiva, este se perfila como el artífice de una suerte de zapping callejero y

24 Aunque mediada, en este caso, por cierto tono autoparódico sugerido por la carga de sensibilidad poco sutil de algunas de sus declaraciones (como el título o el verso inicial: "Amo a las mujeres. ¿Hay algo malo en amar a las mujeres?”, entre muchas otras), además de por la diagramación centrada del poema. 
a escala humana en que a partir de la captura de imágenes — cada una de las cuales va "ocupando su tiempo a la espera de que otra imagen la suceda" (58) y "como si todas . . . estuvieran unidas por 'y', por 'o', por 'ni', o simplemente separadas por puntos" (62) — da cuenta de la capacidad de los sujetos de construir sus propias referencias visuales o su propio imaginario urbano juvenil, en este caso.

La mención del control remoto también permite el traslado de la calle bullente de buena parte de los poemas, al interior de una casa, otro de los espacios centrales de libro. Si bien la fantasía de disponer de muchas mujeres es importante e inquietante para el flâneur-poeta en este mundo constituido como una "pista de baile" en que se busca casi febrilmente con quién(es) bailar, también lo es el mundo de la casa y la expectativa del amor de pareja. Él, configurado en clave autobiográfica e incluso con nombre propio, ${ }^{25}$ parece apostar, como contraparte de lo que ocurre afuera, por la búsqueda de sentidos a través de la realización cotidiana, incluso rutinaria, del amor, la casa y la vida compartida. Esto se ve en poemas como "Los motivos son tantos", ${ }^{26}$ en la carta-poema "Envío (Vía air mail)" ${ }^{27}$ o en pasajes como "No es fácil entender qué significa/ el transporte público/ después de hacer el amor./ Por eso regreso y me escondo en tu pequeño cuerpo,/ porque antes del tiempo existía el deseo/ y ahora estás aquí" (59), en el poema "De pronto miro alrededor".

Desde esta perspectiva, el libro, como varios otros poemarios peruanos de la década, ${ }^{28}$ propone como uno de sus ejes el mundo privado al que de algún modo empujan las ansiedades, temores y presiones de la época (Chueca, "Consagración" 88). La atención a lo privado no sólo es indicio de pérdida de sentidos colectivos y, en esta medida, espacio de refugio frente a la agresión y el desconcierto del entorno,

25 Esto ocurre, por ejemplo, en "Envío (Vía air maih" o en "Tanto amor", el último poema del conjunto.

26 "Te recibo con un libro bajo el brazo/ y en los ojos esos lentes/ que por octava vez/ lograste arreglar.// 'Potito de algodón, digo yo./ 'Cabeza de Cholito', respondes tú./ Y sin implicaciones sociológicas de ningún tipo/ decimos todo lo que nos gusta/ o soportamos oír” (60).

27 "Querida Éricka:// ... falta muy poco/ para tu cumpleaños/ (Esos días hay que llevárselos de acá)// Te ofrezco lo que tengo a mano:/ un paisaje increíble,/ amplias carreteras que conducen/ a bienestares aburridos,/ árboles moviéndose entre árboles/ cemento y barro,/ césped y nieve,/ el aire helado de un Dios monótono/ ...// Un charco de agua/ y las nubes reflejadas en él/ ...// Y dile también a quien te pregunte/ que entre la muerte y yo/ he escogido tu cuerpo,/ aunque esto solo signifique/ que una angustia sin nombre no es carne/ para el espíritu.// Nos vemos el 1 de abril,/ Besos-/ Martín" (34-39).

28 Casa de familia (1995) de Selenco Vega, Cansancio (1995) de Paolo de Lima, Libro de Daniel de Javier Gálvez (1995), Cisnes estrangulados (1996) de Victoria Guerrero o (Nadie se mueva) (1999) de Gastón Agurto, entre otros. 
sino también resistencia al vaciamiento simbólico y a sus consecuencias fundamentales, pues desde esta dimensión íntima y cotidiana el sujeto puede autorreconocerse como individuo, de modo más cabal, en el espejo que representa el otro.

Al final del libro, en el poema "Tanto amor", el hablante confiesa su satisfacción por "haber . . a amargado" a los lectores, resultado de "una pretensión/ quizá un poquito/ trasnochada" (72-73): la de incomodar e interpelar las miradas habituales, algo ajeno a los paradigmas vigentes en los tiempos de escritura del poemario, en que no se enfatizaban las responsabilidades del poeta frente a la sociedad. La escritura le ha permitido abordar algunos de los "fetichismos ideológicos" del mito posmoderno (Grüner 12): evidenciar el vacío provocado por la superficialidad y los simulacros en los que por momentos parece querer sumergirse, a la vez que dar pie a una posible recuperación de la historicidad perdida (Jameson 45-46). Esto último ocurre, por ejemplo, al confrontar sutilmente la idealizada globalización con la realidad precaria de las migraciones tercermundistas a las grandes metrópolis; al enunciar, también muy de pasada y en clave lúdica, una afirmación sobre la inexistencia del Perú como nación, o al referir la violencia política peruana, algo poco frecuente en la poesía durante dicha década. ${ }^{29}$

La "pretensión trasnochada" del contrapunto entre euforia nocturna, convivencia amorosa y sutiles sugerencias historizadoras se sintetiza en estos versos del poema "La eternidad está enamorada de los frutos del tiempo": "Si alguien forja una respuesta/ su respuesta/ nada habrá sido en vano” (55). Guiado por este interés, Rodríguez-Gaona expresó, a través de las estrategias compositivas y los desarrollos temáticos de Pista de baile, algunas tensiones centrales en las subjetividades juveniles del Perú de los años noventa.

\section{Mundos en común en La insidia del sol sobre las cosas}

La insidia del sol sobre las cosas (1998), segundo poemario de Germán Carrasco, también ofrece, como una de sus líneas principales, representaciones de la ciudad hacia fines de siglo, pero a diferencia de Pista de baile, el universo urbano corresponde aquí sobre todo a zonas y barrios de la capital chilena identificados como

29 Sobre lo primero, son interesantes estos versos de "Tanto amor": "Mis amigos del barrio: Moisés,/ los Tamaki, Toño, Pumpi y Corina,/ en Japón, en EE.UU.,/ emigrados como ofertorio a una ley/ económica" (68). En relación con la nación, en "Nada es nada..." leemos: "Seamos optimistas: El Perú/ no existe" (17), "y como el Perú no existe/ (v.g. no como/ en ciertos restaurantes)/ pasaremos por ciudadanos Bolivianos/ Total, fue idea de Ribeyro/ fomentar dicha unión/ para llegar al mundial” (19). En cuanto a la violencia política, en el letánico poema "La eternidad está enamorada de los frutos del tiempo", se mencionan, además de dos referencias internacionales, dos peruanas: "Expurgan sus cuerpos sobre/ Bosnia/ Ruanda/ Soccos/ Tarata" (53; ver al respecto Chueca 2006: 247-249). 
espacios de clases medias-bajas o populares. Grínor Rojo, respecto de Calas (2001), el siguiente libro de Carrasco, señaló que el poeta "le está dibujando a la ciudad de Santiago su fisonomía actual" (76): una urbe "menos focalizada, menos jerárquica, más dispersa y minimalista" (76). Esto es ya visible en La insidia..., en varios de cuyos poemas el hablante poético, recorre espacios públicos (calles, mercados, parques, etc.) o se acerca a observar recintos cerrados que ofrecen, unos y otros, imágenes de la ciudad.

Desde estas coordenadas, los poemas no se limitan al apunte urbanístico, revelador de cartografías sociales, sino que entregan sobre todo imágenes de detalle ("fotografías" las ha llamado Carrasco en diversas entrevistas) ${ }^{30}$ de personajes que habitan o transitan dichos espacios y de situaciones que ocurren con ellos. Capta así las subjetividades en su entorno, lo que le permite el reconocimiento del otro como próximo (prójimo) a pesar de las diferencias, o la aproximación a los sentidos — múltiples por lo general— detrás de sus prácticas o gestos. Todo ello bajo el influjo, según lo sugerido por el título, de una insidiosa luz solar que hace reveladoras las visiones o, al contrario, las vela por deslumbramiento. Miradas, a fin de cuentas, que dislocan las percepciones habituales. ${ }^{31}$

Un poema apropiado para la revisión de estas operaciones es "El mundo se divide en tres", que presenta, correspondiendo a lo anunciado por el título, tres secciones (“(I) Fachadas continuas", "(II) Blocks" y “(III) El flamenco (remanso)"), además de una estancia introductoria, que reproduzco a continuación:

Bajo la insidia solar o en una claridad de fin de lluvia, el mundo se divide en tres:

-las fachadas continuas
-los blocks o villas
-y los parajes

ingleses donde leer p. ej El ruiseñor, y sentarse, y nada (el Botánico de Viña, el Forestal de un Santiago abandonado en vacaciones, algún sector aledaño a una iglesia).

30 Por ejemplo, en 1998, recién aparecido el poemario La insidia del sol sobre las cosas: "Uno hace fotografía o una especie de voyerismo: intenta atrapar la plasticidad y el misterio de las cosas” (Karmelic 3). 31 Martina Bortignon (128-135) ha trabajado sobre las miradas y sus diversos regímenes en la poesía de Carrasco analizando también los procedimientos que en diálogo con el lenguaje cinematográfico alternan en los poemas. 
Las fachadas continuas son para la infidelidad y para caminar à la Prufrock. Las villas

para trabajar estoicamente: cajas

más o menos grandes que interrumpen el crepúsculo

con sus estructuras de República del Este

$y$, lo que no es mucho decir, estas tres partes

son perfectas para el crimen y el amor (16).

Estos versos sintetizan lo que se desarrolla a continuación respecto de la distinción entre los tres tipos de espacios mencionados y las prácticas y comportamientos en cada uno de ellos. Como se observa, las descripciones de los lugares y los objetos que los pueblan están en función de la captación de las dinámicas sociales involucradas en dichos espacios y, sobre todo, de las subjetividades en tensión y en relación en estos. Me concentraré en “(I) Fachadas continuas”, pues permite reconocer aspectos claves del modo de acercamiento del hablante y del poemario a su entorno y, en esa medida, entender cómo procesa el poeta las coordenadas de la época, cómo expresa su mundanidad. La primera estrofa dice:

Las fachadas continuas presuponen un mundo común;

la manzana entera no es sino una sola casa

con pasillos interconexos, atestados

de fotocopiadoras, computadoras en desuso,

carniceros en plena faena, viejos que fuman

y una niña que mira por la ventana y piensa jugar

en la plaza, que es el patio de todos (17).

El fragmento da cuenta de la coexistencia habitacional o de pequeños negocios en barrios tradicionales: casas antiguas muy amplias, pero subdivididas o subarrendadas, en donde todo se conecta o se confunde con todo, estructurando microcosmos necesariamente compartidos, precarios y hasta cierto punto promiscuos, pero vibrantes y vitales, que forman el "mundo común" del que habla el texto. "Común" puede leerse como "habitual" o "corriente", pero también en el sentido de un mundo-en-común, que es la perspectiva que me interesa. Desde sus interconexiones, confusiones y abigarramiento, estos espacios compartidos confrontan las imágenes del mundo privatizado, aséptico y funcional que se iban consolidando en el imaginario del consumo exitoso, como paradigmáticas de un Chile casi primermundista, a ejemplo para toda Latinoamérica (Moulian 97-100; Cárcamo 33-37). 
Bajo este modelo neoliberal, el emblema del espacio público es el shopping center o mall: lugares imaginariamente inclusivos, homogenizadores, higiénicos y eficientes, en donde nada es azaroso y de donde queda excluido todo peligro del afuera. Espacios, a la vez, que ofrecen compensatoriamente a sus visitantes de pocos recursos la posibilidad de comprar algo o al menos sentirse potenciales consumidores (Sarlo, La ciudad 13-34).

Frente al mall como dispositivo que "produce comunidad allí mismo donde parecía haberse perdido para siempre", según la expresión que Sarlo retoma de Jor Jerde (16), el flâneur santiaguino de La insidia..., busca y propone otro tráfico de imágenes de la ciudad: aquellas en que se configuran otras formas de comunidad. En esa perspectiva recorre y fotografía espacios habitualmente no atendidos, ilumina relaciones no descubiertas o proximidades no reveladas entre los sujetos, y percibe deseos o sensaciones comunes, pero habitualmente no declarados. O plantea preguntas no para ser respondidas, sino para que queden rondando en el lector.

Esto último sucede, por ejemplo, en el tercer poema del libro, "Todo claro como el agua incuestionable", cuya primera parte ("I/ Todas las fachadas continuas / Todas las historias que esconden/ Todos los blocks y los parques ingleses/ como el Forestal en el verano de un Santiago vacío"; 9) anticipa lo que se leerá luego en el mencionado "El mundo se divide en tres", el octavo del conjunto. En "Todo claro como el agua incuestionable", una de "[t]odas las historias que esconden" es la que presenta la parte $\mathrm{V}$, en que alguien, quizá el propio hablante referido en tercera persona o la niña de la que se habla en la parte anterior:

[a] veces sale a horas sospechosas

cerrando puertas en silencio

o mira por la hendidura cómo rezan

y fuman las mujeres en lo oscuro.

Se pregunta por qué

para qué fuman y rezan

y por quién".

Ese tipo de preguntas o historias escondidas pueblan los "mundos comunes" de los poemas. Pero no se trata de despertar vanas o vacuas curiosidades, sino de darles "patente de existencia a lugares y a subjetividades que no la tenían hasta el momento de ser escritas" (Carrasco, A mano 171)".

Si pensamos que es la niña quien sale de la casa a hurtadillas, queda implícito un juego de miradas refractadas: el hablante del poema ve a la niña mientras esta ve algo, que a su vez (o por ello) el hablante llega a ver. Las miradas escapan de las 
visiones directas y unívocas y provocan cierta identificación entre ambas. Algo semejante ocurre en "(I) Fachadas continuas", en donde se produce una "seducción imaginaria" (Bortignon 129) entre el hablante-voyeur y su imaginada interlocutora, una adolescente que también fisgonea en el "célebre laberinto" de las "fachadas continuas", abierta a la experimentación y al hallazgo. Nuevamente no hay contacto directo entre ellos, sino que él la mira desde un lugar que ella no ve y le dirige comentarios, confesiones o indicaciones que la muchacha no percibe. Ella, por su parte, sigue en su propia búsqueda con curiosidad y deseo semejantes a los del hablante. Y a pesar de que la comunicación real está bloqueada, es claro que sus miradas se vinculan: él mira lo que ella mira o lo que está a punto de mirar:

en un cuarto un parto o un aborto, en otro un estudiante pobre lee a Marx o al Führer y luego busca trabajo en los Clasificados Económicos (haz la prueba, interrúmpelo), en otro una niña hace sus tareas escolares o un fisicoculturista infla sus músculos y hasta hay gente que reza (18).

Quizá la sensualidad y la sexualidad que exuda el poema representan no sólo la atracción del hablante hacia la muchacha, sino también el estallido del hallazgo, la epifanía: la implícita conexión entre ambos, y la complejidad y riqueza de ese espacio que los vincula, imposible de clasificarse bajo alguna etiqueta que empobrecería sus proliferantes sensaciones. ${ }^{32}$ Tal vez por eso al final el hablante le dice, utilizando un "nosotros" que no había aparecido y que parece implicar también a los lectores: "Este es el paisaje. Continuemos el recorrido/ y sus consecuencias" (18).

Esta es, sin duda, una de las propuestas centrales de los "poemas urbanos" de La insidia.... emprender recorridos y descubrir a través de ellos esos mundos-en-común entre sujetos singulares y diversos (y no estigmatizables) ${ }^{33}$ que comparten una calle, un barrio o una ciudad. Los poemas apuestan por presentar escenas que discuten los "mapas de lo visible" (Rancière, El reparto 49) difundidos en Chile

32 Respecto de lo que la niña y, con ella, el hablante, llegan a observar, Bortignon señala que "al mezclar tales situaciones con la normalidad de las faenas de todos los días, la instancia escritural consigue poner en juicio el concepto mismo de normalidad", a partir de su interés en "desorientar al lector en sus mecanismos de evaluación de un fenómeno dado” (131).

33 Para Carrasco, su ciudad "no ... tiene que ser estigmatizada como marginal. No, al contrario, como dice el tango, se trata de una nobleza de arrabal. ... de mezclar lo elegante y lo demótico” (Montecinos 22). 
afin de siglo, y por abrir la posibilidad de imaginar otras formas de comunidad. ${ }^{34}$ Dar "patente de existencia" a esa posibilidad a través del acercamiento a "lugares y subjetividades" que no habían recibido mucha atención, es, según ha señalado Carrasco (A mano 171), la política que la poesía puede ejercer. Esta noción, o la implicada cuando anota que "[l]a literatura, si es que tiene alguna función, es la de ampliar el mundo" (A mano 102), coinciden con la idea de Rancière cuando afirma que "hay una política de la estética en el sentido en que las formas nuevas de circulación de la palabra, de la exposición de lo visible y de producción de los afectos determinan capacidades nuevas, en ruptura con la antigua configuración de lo posible" (El espectador 65).

La política no implica aquí, como se desprende de lo revisado, rememorar el pasado dictatorial ${ }^{35}$ ni hablar expresamente de sus continuidades en el presente de la Transición, pero sí involucra un enfrentamiento tácito con algunos de sus legados más importantes. Así, sin pretender el retorno de las utopías emancipatorias ni la reactivación de lo colectivo en algún sentido cercano al que se sostenía frente a la dictadura, ${ }^{36}$ los poemas se alejan de las lógicas socioeconómicas neoliberales, predominantes en el Chile de fin de siglo. Al hacerlo, alejándose a la vez de las estéticas neovanguardistas o del ejercicio de una poética de denuncia y confrontación directa, como las que se desarrollaron en la década anterior, ofrecen una clara evidencia de su inscripción y sus modos de existencia en su tiempo de producción.

La distancia frente a las lógicas del mercado neoliberal se expresa también en la toma de posición del poeta ante la creación, tal como se sugiere en algunas de las numerosas artes poéticas del libro. En relación con esto, Rojo ha señalado que Carrasco retoma el lema "lavorare stanca" del italiano Cesare Pavese, que reescribe

34 En un sentido semejante al que se refiere Silvia N. Rosman al hablar del "ser en común" como una posibilidad de "articular un pensamiento no fundacional y no-esencialista de la comunidad basado en una relación ética con el otro y en la exigencia política de un 'nosotros' .... Formas de comunidad que no dependan de lo que Rancière llama el orden policíaco” (119), es decir, la organización de los hombres en comunidad a partir de "la distribución jerárquica de lugares y funciones" (Rancière, Política 17)

35 Salvo mínimas excepciones: en "Traductora" se habla de una chica que salió del país "en plena democracia" (31); esta frase, en cursivas, resalta la particularidad del caso y recuerda a los que debieron salir en dictadura. En "Oficio" la mención de "la tortura" también remite al período dictatorial. Esta ausencia de referencias, compartida en general por los poetas de los años noventa (también en el Perú respecto de la violencia política), ha sido argumento frecuente para hablar de la despolitización de esta promoción.

36 Sobre la escena universitaria de la década de los noventa, a la que pertenecían varios poetas, Carrasco escribe: "Varios venían de grupos que se la habían jugado sin asco en los ochenta, y ... estaban todos cansados y no creían en absolutamente nada en términos políticos" ( $A$ mano 133). 
como "la praxis lisia", ${ }^{37}$ en el sentido de una declaración de renuncia a la dinámica del horizonte de vida productiva desde el modelo burgués, como una condición necesaria para su apuesta por la escritura. Esto supone, a su vez, una opción por la precariedad que refuerza su alejamiento de los postulados acerca del éxito medido en las posibilidades de consumo (79).

Este rechazo a las dinámicas centrales del neoliberalismo lleva al poeta-flâneur de La insidia... a proponer otras lógicas para el tráfico y la circulación de las imágenes, tanto las que recibe como las que produce. Esto se observa, por ejemplo, en el poema "El mercado", el cual entrelaza comentarios sobre los exaltados hallazgos, regateos, compras y ventas en un amanecer en las calles aledañas, quizá, al mercado de La Vega, o en los pasajes del mercado anticuario ("persa"), con apuntes sobre escritura y retórica, y muestras de pastiches, composiciones y trabajos de montaje.

En su recorrido, el poeta-flâneur encuentra vestidos, alimentos, chatarra y baratijas; anuncios a voz en cuello y micros que avanzan con dificultad; "lanzas a chorro que huyen entre gritos" (60), transpiración y emociones; objetos que han quedado como ruinas aprovechables de otros tiempos, retazos de memoria, fantasías, deseos y frustraciones. Todos estos objetos, eventos y sensaciones, que coexisten en "un modo de visibilidad que ... revoca las jerarquías de grandeza de la tradición representativa" (Rancière, El reparto 41), constituyen el universo de materiales comunes disponibles para la construcción de su poema. "Algo se encuentra en esta arqueología" (59) dice en uno de los versos y el lema parece haber guiado no sólo el recorrido de este poema, sino el trazado de esta visión de la ciudad que se yergue en La insidia..., una renuente a las lógicas privatizadoras y los consumos individualistas.

La mención de la "arqueología” remite también a la poética: no sólo los materiales encontrados, sino los modos de trabajar con ellos. Y así como ocurre en "El mercado", en casi todos los poemas las imágenes de la ciudad que se construye coexisten con referencias y alusiones metapoéticas que le hacen contrapunto. Es oportuno por ello, para cerrar esta revisión, destacar la diversidad de procedimientos que se ensayan a través de todo el libro: versos de sonoridad leve al lado de estrofas densas y concentradas, que llevan al interior de un mismo poema ritmos y velocidades distintos, ${ }^{38}$ alternancias entre verso y prosa ${ }^{39}$ y entre fragmentos líricos

37 Se refiere a esto con relación a Calas, pero ya en La insidia... aparecen varias menciones semejantes. 38 Como en "Bombalurina" (61-62), en que a la primera parte, de versos breves y de delicada musicalidad, casi al modo de un haiku, le sigue una segunda con estrofas de versos extensos y enérgicos de dicción coloquial.

39 Esto se observa, por ejemplo, en el poema: "Elegía de hielo/ Partitura de un réquiem/ Para no interpretarse/ Responso con las manos en la cara/ Exequias de la mudez/ El velo. El sello” (70-72), cuyo 
y narrativos,${ }^{40}$ aparentes divagaciones,${ }^{41}$ enumeraciones,${ }^{42}$ encabalgamientos, poemas-collage, ${ }^{43}$ paralelos temáticos, ${ }^{44}$ reiteraciones de motivos entre diferentes poemas, ${ }^{45}$ profusa intertextualidad, entre un sinnúmero de otros procedimientos que proponen el acercamiento al poemario como una experiencia estética hasta cierto punto desestabilizante respecto de las prácticas habituales de lectura.

$\mathrm{Al}$ respecto, Carrasco ha señalado "que el libro tiene que tener poemas distintos, estilos, etc.: diamantes formales, fárrago, ritos, llanto, guiños a la tradición, poemas que aparentemente parecen comentarios banales, notas, retórica profunda, amor y muerte; álbumes de toda especie de poemas, unidos por los distintos registros de una voz" (Montecinos 20). También de este modo se configura la política en La insidia del sol sobre las cosas, pues si bien la pluralidad de registros dialoga con la celebración de lo diverso y la hibridez de las estéticas posmodernas, se enfrenta a la vez, al ocurrir esto en un sólo libro e incluso en un mismo poema, a las lógicas de consumo literario que buscan organizar y clasificar, construyendo casilleros que puedan convertirse fácilmente en mercancías.

título es ya un anuncio de la multiplicidad del texto, que no se limita a la alternancia señalada.

$40 \mathrm{Al}$ inicio de "La separación de los siameses": "Esta es tu mirada y tu sonrisa/ piscina plena virtutis,/ divinun vinum Franciscal (y demás diminutivos y carantoñas: claro signo de decadencia/ con sabor a quedarse en cama juntos sorbiendo cerveza,/ tirando todo el santo día)" (58).

41 Todo el poema "Héctor Figueroa mirando las estrellas" es un monólogo en que el personaje mencionado se va configurando a sí mismo como sujeto a través de una serie de apuntes diversos sobre su vida, sus deseos, su escritura, etc., que no siguen una línea definida.

42 Entre muchos ejemplos posibles, en “(2) Blocks” se lee: "En estos habitáculos de ladrillo princesa tipo República Socialista, en donde fue filmado El Proceso de Kafka -Wells-, Caluga o Menta de Justiniano, The Rear" y más adelante "Las calles se llaman: El esfuerzo, El empeño, La Perseverancia, La Constancia, etc., exceptuando la avenida principal: Patria Nueva. Villas. El sol recalienta los taxis Lada estacionados y seca rápidamente sábanas, camisas, calzones y demás banderas de rendición que estilan sudor, manchas y agua bendita que le cae a uno al pasar" (19). Es interesante observar el efecto rítmico de las enumeraciones al interrumpir el flujo narrativo del poema.

43 Como en el caso de "Bop \& Free Jazz" (33-34). El procedimiento de base para casos como este es el montaje, constante en todo el poemario.

44 En "El mercado" (59-60), como vimos, se entrelazan la configuración del espacio urbano aludido y la reflexión metapoética a partir de los mismos elementos y los modos de relación del hablante con ellos.

45 Como ocurre, por ejemplo, en distintos poemas con los tres (o alguno de los tres) espacios emblemáticos del Santiago representado (fachadas continuas, block y parques ingleses) o con el lema "la praxis lisia", en los poemas "Amague" (43-44), "Diosa de la nieve" (65), “Julián en la mesa” (82) o "Sello" (90). 


\section{Apuntes finales}

No es posible proyectar lo analizado en las páginas anteriores a todos los poetas chilenos y peruanos de la promoción de los noventa, ni todo lo que podría comentarse respecto de estos se puede identificar en Pista de baile y La insidia del sol sobre las cosas. No obstante, lo hallado respecto de estos dos poemarios es un ejemplo de algunos de los modos en los que los poetas que comenzaron a publicar en ambos países en dicha década procesaron, a través de sus respectivas escrituras, los cambios sociohistóricos, ideológicos y culturales que se vivían. Es decir, de cómo sus estrategias de composición, lenguajes, ritmos e imágenes, así como los temas que abordaron y las perspectivas desde las que lo hicieron, evidenciaban que sus modos de existencia estuvieron entrelazados inevitablemente con las circunstancias de su tiempo y de su sociedad (Said 54). Para cerrar esta revisión con unos apuntes conjuntos sobre Pista de baile y La insidia del sol sobre las cosas en el marco de las características comunes en las poéticas de la década de los noventa, será útil retomar las mencionadas en el primer acápite de este trabajo.

Dejando de lado la diversidad, posiblemente el rasgo que más acerca a ambas escenas poéticas, pero que es difícilmente comprobable en un cotejo de sólo dos autores ${ }^{46}$ puede mencionarse, en primer lugar, la ausencia de un horizonte utópico en los dos poemarios, en donde no aparece ni siquiera como referencia histórica. Para la promoción anterior, el ideologema de la revolución (o al menos cierta expectativa de redención colectiva) todavía era frecuente, aunque fuera - más claramente desde fines de los años ochenta- para reconocer su crisis o su imposibilidad. Para los poetas de los noventa, esta figura desaparece casi totalmente de sus textos de esta década ${ }^{47}$ en consonancia con la aparente despolitización y el alejamiento de los poemas de las preocupaciones o de las imágenes totalizantes. Se configuran, en cambio, múltiples heterotopías (Bello, parte IV, párr. 4-6): espacios

46 Aunque, como se ha visto, se puede identificar un interés por lo diverso en la multiplicidad de registros y lenguajes en La insidia... y en la variedad de perspectivas en juego en Pista de baile (la eufórica diversión, el ámbito privado de la pareja y el amor y la postura sutilmente historizadora).

47 A partir del año 2000, reaparece en varios de ellos. Por ejemplo, en el Perú, en Ya nadie incendia el mundo (2005) y Berlin (2011) de Victoria Guerrero, Ludy D (2006) de Roxana Crisólogo; y en Chile, en La noche del zelota (2013) de Camilo Brodsky o La casa de Trotsky (2011) de Cristián Gómez Olivares. También es aludida en Multicancha (2006) de Carrasco, poemario de mayores resonancias políticas expresas. Algo semejante ocurre con los libros posteriores a Pista de baile de Rodríguez-Gaona: Parque infantil (2005) y sobre todo Codex de los poderes y los encantos (2011). Desde estas constataciones se abre una sugerente línea de indagación: ¿qué sucede con la aparente despolitización de los poetas de los noventa pasada esta década? Respecto de la poesía peruana de esta promoción y la violencia política se puede revisar Chueca, "Poesía y violencia política..." 
diversos, polivalentes y compensatorios frente a la derrota de la utopía. En Pista de baile estos se pueden asociar tanto a los lugares de diversión como a los recintos privados del amor. En La insidia..., por su parte, se identifican en los diversos espacios recorridos, pequeños recintos en los que es posible descubrir, al menos fugazmente, mundos-en-común.

Frente a lo colectivo, otro nudo de modificaciones en los años noventa, los poemarios permiten identificar cierto nosotros ajeno a cualquier programa definido. En Pista de baile puede vincularse, por un lado, con la pretensión del hablante de impactar o incomodar a los lectores con la expectativa de que forjen sus propias respuestas y, por otro, con la pulsión hacia la mínima comunidad en la pareja. Esto se contrapone a lo que ocurre con los sujetos disgregados y anómicos que, si bien comparten espacios de diversión ritual, no constituyen una instancia colectiva por sus casi nulas posibilidades de mutuo reconocimiento. En La insidia..., en que uno de los ejes es la posibilidad de imaginar mundos-en-común, estos tensionan la idea de lo colectivo por la fugacidad de los reconocimientos: la comunidad posible aparentemente es ajena a cualquier decisión de acción colectiva.

Tensiones semejantes también se observan respecto de la participación de los poetas en el campo literario, pues los grupos surgidos en la década de los noventa, que contribuyeron a activar la escena, funcionaron más como plataformas de intercambio, acompañamiento e incorporación al campo que como colectivos que compartieran algún programa estético-ideológico. Esto involucra a poetas como Rodríguez-Gaona y Carrasco, quienes participaron de talleres, de la Universidad de Lima y de la Fundación Neruda, respectivamente, pero los percibieron, como comenta Carrasco, "básicamente [como] instancias de amistad, reuniones de camaradería" (García 27) en donde se compartían lecturas y se comentaban textos, propios o ajenos, sin pretender articular proyectos de acción conjunta o poéticas comunes.

En concordancia con lo anterior, se abandonan también las convicciones sobre incidencia efectiva de la poesía en los destinos de la sociedad. Aunque ya desde los años ochenta esta posibilidad estaba en discusión, la década de los noventa selló el escepticismo. Pero como se comprueba con los poemarios revisados, al menos algunos poetas de esta promoción persistieron en el ejercicio crítico respecto de la realidad. Las expectativas parecen limitarse, sin embargo, a la visibilización de ciertas zonas de la realidad (sujetos, espacios, situaciones), a la formulación de tácitas distancias respecto del neoliberalismo imperante y a la sugerencia de ciertas 
modalidades de comunidad ajenas a las propuestas colectivas totalizantes, pero también a las propiciadas por las lógicas del consumo.

Es interesante reconocer, en relación con esto, que si bien ambos poemarios se inscriben en los marcos de las estéticas posmodernas vinculados con "la lógica cultural del capitalismo avanzado" según Jameson, no renuncian a ser productos hasta cierto punto incómodos, y en esta medida generadores de miradas críticas, también desde sus aspectos formales y su materialidad significante. Carrasco, por ejemplo, por la diversidad de registros, tonos y lengaujes que utiliza, que impide una fácil clasificación en algún casillero del canon poético, y Rodríguez-Gaona por su hipercoloquialidad, que acerca a los poemas a la experiencia de lo cotidiano y pone en cuestión los paradigmas habituales de lo poético.

La tentación de lo privado es otro rasgo importante en la poesía joven peruana y chilena en la década de los noventa. Representa un refugio, habitualmente, pero también resistencia, como ocurre en Pista de baile, en donde los espacios de la intimidad cotidiana están en constante contrapunto con lo público y con la voluntad historizadora. En La insidia..., por su parte, los espacios privados a los que atienden los poemas (contrapuestos a la idea de lo privatizado) son necesarios soportes para la configuración de los mundos-en-común. En esta aventura resultan indispensables el fisgoneo y otras posibilidades de la mirada, que nos llevan al terreno de las estrategias de composición del poema.

Finalmente, entre otros procedimientos utilizados que aprovechan intensamente, como en buena parte de la poesía de la década de los noventa, tanto el repertorio de las estéticas modernas como de las posmodernas, conviene mencionar una de las privilegiadas a partir de la condición de flâneur de los hablantes-poetas que transitan las calles en busca de los fragmentos y materiales disímiles (imágenes, sujetos, tonos, temporalidades, objetos, etc.) para sus poemas: el montaje, dispositivo que supone la conciencia crítica del que lo organiza y requiere de la participación activa del lector. Para ambos es claro, como señala el filósofo del arte Georges Didi-Huberman, que "[e]l montaje sólo es válido cuando no se apresura demasiado en concluir o en clausurar de nuevo, es decir cuando inicia y vuelve compleja nuestra aprehensión de la historia, no cuando la esquematiza abusivamente. Cuando nos permite acceder a las singularidades del tiempo, luego a su esencial multiplicidad" (180).

Aunque mucho más podría decirse, valga apuntar, para cerrar estas páginas, que una tradición poética se teje, más que de cortes abruptos, a partir de continuida- 
des. Entre ellas, sin embargo, ciertos momentos representan más vívidamente la confluencia de procesos sociohistóricos y culturales con cambios en los rasgos de escritura y en las concepciones respecto del trabajo poético. Esto ocurrió, como se desprende de lo visto, en los años noventa con la poesía joven en Chile y Perú, dos escenas poéticas con muchos aspectos en común. 


\section{Obras citadas}

Álvarez, Montserrat. Zona dark. Lima: (edición de la autora), 1991.

Bauman, Zygmunt. Vidas desperdiciadas. La modernidad y sus parias. Trad. Pablo Hermida Lazcano. Barcelona: Paidós, 2005.

Bello, Javier. "Los náufragos". Poetas chilenos de los noventa: Estudio y antología. Tesis. Universidad de Chile, 1998. Web. 15 Ago. 2018. < http://www.uchile.cl/cultura/ poetasjovenes / framenaufragos.htm $>$

Bernales, Enrique y Carlos Villacorta, eds. Los relojes se han roto. Antología de poesía peruana de los noventa. Guadalajara: Arlequín, 2005.

Bolle, Willi. Fisiognomia da metrópole moderna: Representação da história em Walter Benjamin. Sao Paulo: Editora da Universidade de Sao Paulo, 2000.

Bortignon, Martina. Margen, espejo. Poesía chilena y marginalidad social (1983-2009). Pittsburgh: IILI, 2016.

Brito, Eugenia. Campos minados (Literatura post-golpe en Chile). Santiago de Chile: Cuarto Propio, 1994.

Cárcamo-Huechante, Luis. Tramas del Mercado. Imaginación económica, cultura pública y literatura en Chile de fines del siglo veinte. Santiago: Cuarto Propio, 2007.

Cárcamo-Huechante, Luis y José Antonio Mazzotti. "Dislocamientos de la poesía latinoamericana en la escena global". Revista de Crítica Literaria Latinoamericana 58 (2003): 9-21.

Carrasco, Germán. La insidia del sol sobre las cosas. Santiago: J.C. Sáez, 2003 [1998].

Carrasco, Germán. A mano alzada. Santiago: Cuarto Propio, 2013.

Cerón, Rocío, Julián Herbert y León Plascencia Ñol, eds. El deciry el vértigo. Panorama de la poesía hispanoamericana (1965-1979). México D.F. Filodecaballos \& Conaculta, 2005.

Chueca, Luis Fernando. "Consagración de lo diverso. Una lectura de la poesía peruana de los noventa”. Lienzo 22 (2001): 61-132.

Chueca, Luis Fernando. “¿La hegemonía de lo conversacional? Notas para continuar una discusión”. Intermezzo Tropical 6-7 (2009): 134-140. 
Chueca, Luis Fernando. "Martín Rodríguez-Gaona: He amado esta ciudad en todas sus formas". En la comarca oscura. Lima en la poesía peruana 1950-2000. Luis F. Chueca, Carlos López Degregori y José Güich. Lima: Universidad de Lima, 2006. 231-249.

Chueca, Luis Fernando. "Poesía y violencia política en los poetas de los años noventa en el Perú (revisión panorámica y estudio del caso de Ya nadie incendia el mundo, de Victoria Guerrero)". En líneas generales 1 (2018). 71-83. Web. 23 dic. 2019. < https://revistas.ulima.edu.pe/index.php/enlineasgenerales/article/ view/1832>

Comisión de la Verdad y Reconciliación (CVR). Informe Final. 2003. < https://www. cverdad.org.pe/ifinal/index.php $>$ [12 mar 2012].

Degregori, Carlos Iván. La década de la antipolítica. Auge y buida de Alberto Fujimori y Vladimiro Montesinos. Lima, IEP, 2000.

De Lima, Paolo. "Vivo en un lugar memorable. Entrevista con Martín RodríguezGaona”. El Sol. 7 abr. 1997. 7B.

Didi-Huberman, Georges. Imágenes pese a todo. Memoria visual del Holocausto. Trad. Inés Bértolo. Madrid: Paidós, 2011.

Dobry, Edgardo. "Zeigeist zurdo". Zur Dos. Última poesía latinoamericana. Antología. Eds. Yanko González y Pedro Araya. Bs. As.: Paradiso, 2004. 247-254.

Eguiluz, Luisa. Santiago: fragmentos y naufragios. Poesía chilena del desarraigo (1973-2010). Santiago: Catalonia, 2013.

Fukuyama, Francis. El fin de la historia y el último hombre. Barcelona: Planeta, 1992.

García, Javier. "La mirada de un francotirador" (entrevista a Germán Carrasco). La Nación. 6 oct. 2005. 27.

Grüner, Eduardo. El fin de las pequeñas historias. De los estudios culturales al retorno (imposible) de lo trágico. Bs. As.: Paídós, 2002.

Guerrero, Gustavo, ed. Cuerpo plural. Antología de la poesía hispanoamericana contemporánea. Valencia: Pre'Textos, 2010.

Guerrero, Victoria. "Entre el desencanto y la violencia -a manera de testimonio-". Revista virtual Ómnibus 13 (2006). Web. 22 sept. 2018 < http://www.omni-bus. $\mathrm{com} / \mathrm{n} 13 /$ guerrero.html $>$

Guillén, Paul. Aguas móviles. Antología de poesía peruana 1978-2006. Lima: Perro de ambiente, 2016. 
Gutiérrez, Julián, ed. Fin de siglo. Nueva poesía de los 80. Santiago: Ventana Abierta, 2009.

Hernández Montecinos, Héctor. Buenas noches luciérnagas. Santiago: RIL, 2017.

Hopenhayn, Martín. "Tribu y metrópoli en la postmodernidad latinoamericana". Enfoques sobre posmodernidad en América Latina. Eds. Roberto Follari y Rigoberto Lanza. Caracas: Fondo Editorial Sentido, 1998. 19-35.

Ildefonso, Miguel. “Algunos apuntes sobre poesía actual”. Blog MDIH. 2004. Web. 22 sept. 2018. < http://metapapeles.blogspot.com/2005/10/algunos-apuntessobre-poesia-actual.html>

Jameson, Fredric. Elposmodernismo o la lógica cultural del capitalismo avanzado. Trad. José Luis Pardo. Barcelona: Paidós, 1995.

Karmelic, Roberto. "Las letras de algunas bandas son tremendos poemas" (entrevista a Germán Carrasco). El Mercurio (suplemento) 11 sept. 1998.

Lange, Francisca, ed. Diecinueve (Poetas chilenos de los noventa). Santiago: J.C. Sáez Editor, 2006.

Lipovetsky, Gilles. La era del vacio. Ensayos sobre el individualismo contemporáneo. Trad. de Joan Vinyoli y Michèle Pendanx. Barcelona: Anagrama, 2000.

Lyotard, Jean-Francios. La condición posmoderna. Trad. Mariano Antolín Rato. México: REI, 1990.

Mansilla, Sergio. "¿Para qué poesía en tiempos de desigualdad? Imaginación, memoria y política de la escritura en el contexto de la "cultura de mercado" en el Chile del Bicentenario". Chile mira a sus poetas. Eds. Paula Miranda y C.L. Fuentes-Vásquez. Santiago: PUC y Pfeiffer, 2011. 86-96.

Milán, Eduardo. "En torno a una posible situación de la penúltima poesía latinoamericana". El decir y el vértigo. Panorama de la poesía hispanoamericana (1965-1979). Eds. Cerón, Rocío, J. Herbert y L. Plascencia Ñol. México D.F. Filodecaballos \& Conaculta, 2005. 390-395.

Montecino, Marcelo. "Germán Carrasco. Vértigo de la escritura" (Entrevista). La Calabaza del Diablo 18 (2002): 20-22.

Morales, Andrés. "La poesía de los noventa". Seminario Nueva Poesía Chilena. Web 15 ago. $2018<\underline{\text { http://seminarionuevapoesiachilena2014.blogspot.com/2014/02/ }}$ la-poesia-de-los-noventa-1997.html>

Moulian, Tomás. Chile actual. Anatomía de un mito. Santiago: Lom, 2002. Impreso. 
Ortega, Julio, ed. Antología de la poesía latinoamericana: el turno y la transición. México D.F.: Siglo XXI, 2005.

Rancière, Jacques. Política, policía, democracia. Trad. María E. Tijoux. Santiago: Lom, 2006.

Rancière, Jacques. El reparto de lo sensible. Estética y política. Trad. C. Durán, H. Peralta, C. Rossell, I. Trujillo y F. de Undurraga. Santiago: Lom, 2009.

Rancière, Jacques. El espectador emancipado. Trad. Ariel Dilon. Buenos Aires: Manantial, 2011.

Rioseco, Marcelo. Maquinarias deconstructivas. Poesia y juego en Juan Luis Martinez, Diego Maquieira y Rodrigo Lira. Santiago. Cuarto Propio 2014.

Rodríguez-Gaona, Martín. Pista de baile. Lima: Santo Oficio, 1997.

Rojo, Grínor. “La poesía inteligente de Germán Carrasco”. Mapocho 50 (2001): 75 83.

Rosman, Silvia N. "La comunidad por-venir". Araucaria. Revista Iberoamericana de Filosofía, Política y Humanidades 13 (2005): 107-123.

Rowe, William. Hacia una poética radical: Ensayos de hermenéutica cultural. México D.F.: FCE, 2014.

Ruiz, Carlos. "Democracia, consenso y memoria: una reflexión sobre la experiencia chilena". Ed. Nelly Richard. Politicas y estéticas de la memoria. Santiago: Cuarto Propio, 2000.

Said, Edward W. El mundo, el texto, el crítico. Trad. de R. García. Bs. As.: Debate, 2004.

Salazar, Ina. "Últimas exploraciones en Lima la horrible en la nueva poesía peruana”. Ed. Teresa Orecchia-Havas. Les villes et la fin de XXe. siecle en Amerique latine: Littératures, cultures, représentations / Las ciudades y el fin del siglo XX en A. L.: literaturas, culturas, representaciones. Bern: Peter Lang, 2007. 117-140.

Santiváñez, Roger. "Una generación atropellada”. El Sol. 27 abr. s/p. 1996.

Sarlo, Beatriz. Escenas de la vida posmoderna. Intelectuales, arte y violencia en la Argentina. Bs As.: Ariel, 1994.

Sarlo, Beatriz. La ciudad vista. Mercancías y cultura urbana. Bs. As.: Siglo XXI, 2010.

Sepúlveda, Magda. Ciudad quiltra. Poesía chilena (1973-2013). Santiago: Cuarto Propio, 2013. 
Poesía joven y fin del siglo XX: contrapuntos entre Perú y Chile...

Luis Fernando Chueca

Ubilluz, Juan Carlos. Nuevos súbditos. Cinismo y perversión en la sociedad contemporánea. Lima: IEP, 2006.

Véjar, Francisco, ed. Antología de la poesía joven chilena. Santiago: Universitaria, 2012.

Yrigoyen, José Carlos. La hegemonía de lo conversacional. Algunos apuntes sobre poesía peruana última (1998-2008). Lima: Lustra - Centro Cultural de España, 2008.

Žižek, Slavoj. El espinoso sujeto. El centro ausente de la ontología política. Trad. de Jorge Piatigorsky. Bs. As.: Paidós, 2001. 